\title{
Obstáculos Políticos à Advocacia Sanitária no Brasil: A Pesquisa com Células-tronco Embrionárias
}

\author{
POLITICAL OBSTACLES TO THE SANITARY ADVOCACY IN BRAZIL: \\ THE RESEARCH WITH EMBRYONIC STEM CELLS
}

\author{
Marco Aurélio Antas Torronteguy(*) \\ Luciane Raupp ${ }^{(* *)}$
}

\section{RESUMO}

Advocacia lato sensu tem por objeto a reivindicação de um direito. No Brasil, a Constituição Federal de 1988 reconheceu a saúde como um direito fundamental, abrindo espaço para se falar em advocacia em saúde. Este trabalho busca desvelar os obstáculos políticos ao exercício da advocacia sanitária em geral, a partir da análise de um caso específico - a disputa pela liberdade de pesquisa com células-tronco embrionárias, regulamentada pelo art. $5^{\circ}$ da Lei de Biossegurança, contestado em sede de Ação Direta de Inconstitucionalidade (ADI n. 3.510), atualmente em curso no Supremo Tribunal Federal. A metodologia empregada foi de estudo de caso documental (utilizado para a exposição do problema, do direito reivindicado, do diagnóstico da situação, das estratégias da advocacia e da identificação dos óbices políticos) e do método indutivo (para a composição de um roteiro de identificação de impedimentos à advocacia sanitária em geral).

\section{Palavras-chave}

Advocacia em Saúde; Células-tronco Embrionárias; Direito à Saúde.

\section{ABSTRACT}

Generally speaking, Advocacy's objective is to claim a right. 1988 Brazilian Federal Constitution has recognized health as a constitutional human

(*) Advogado, doutorando em Direito da Universidade de São Paulo. E-mail: <marcoaurelio@usp.br> ${ }^{(* *}$ Psicóloga, doutoranda em Saúde Pública pela Universidade de São Paulo. E-mail: <lucianeraupp@usp.br>. 
right which has initiated public debates about sanitary advocacy. This works seeks to bring out the politics obstacles to the practice of sanitary advocacy, starting with an analysis of a specific case - the dispute for freedom to carry on scientific research with embryonic stem cells, regulated by $5^{\text {th }}$ article of Biosecurity Act, which has been contested to the Brazilian Supreme Court (by an Ação Direta de Inconstitucionalidade - ADI 3.510). The methodology used was a case study (used to explain the problem and the right claimed, to make a diagnosis of the situation, to present the strategy of advocacy and to identify political obstacles) and the inductive method (to compose a guide-book to identify political obstacles to sanitary advocacy in general).

\section{Keywords}

Embryonic Stem Cells; Health Advocacy; Right to Health.

\section{INTRODUÇÃO}

A advocacia em sentido amplo tem por objeto a reivindicação de um direito. Assim, falar em advocacia em saúde é falar em reivindicação do direito à saúde. No Brasil, foi com a Constituição Federal de 1988 (CF/88) que a saúde foi reconhecida como um direito fundamental. O novo ordenamento constitucional possui a característica da participação popular, seja individualmente ou por meio de associações civis. Portanto, a nova Constituição abriu espaço para se falar em advocacia em saúde no Brasil(1).

Reivindicar um direito, ou seja, advogar, é uma atividade que pode acontecer em quatro situações distintas. Em um primeiro plano, a advocacia é a reivindicação pelo reconhecimento de determinado direito, vale dizer, pela sua positivação no ordenamento jurídico. Em um segundo nível, quando o direito já houver sido reconhecido, a advocacia pode direcionar-se à criação de garantias para o direito reconhecido. Em terceiro lugar, por vezes, existem tanto o direito como as suas garantias, mas falta-lhes, por alguma razão, efetividade. Enfim, é possível ainda que a dificuldade política esteja na necessidade de derrogação ou alteração de uma lei vigente.

O presente trabalho faz uma análise de um processo de advocacia sanitária atualmente em curso no Brasil. Trata-se da defesa da constitucionalidade da pesquisa com células-tronco embrionárias, conforme a Lei n. 11.105/05. $\mathrm{O}$ art. 5을 desta lei foi contestado mediante a Ação Direta de Inconstitucionalidade

(1) DALLARI, S. G. El derecho a la salud en la nueva constitución brasileña. In: OPS: el derecho a la salud en la nueva Constitución brasileña. Washington: OPS, 1992. p. 11. 
de número 3.510 (ADI n. 3510), que tramita no Supremo Tribunal Federal (STF). A partir desse caso, tentar-se-á traçar um quadro geral das dificuldades enfrentadas em um processo de advocacia sanitária.

Costuma-se identificar, neste processo, quatro etapas ${ }^{(2)}$. O presente trabalho se estruturou de acordo com elas. A primeira trata da identificação precisa do objeto da advocacia (III). A segunda etapa diz respeito ao diagnóstico da situação, o que implica na análise das variáveis em jogo (IV). Em seguida, o processo de advocacia trata da formulação de estratégias e definição dos passos da ação política (V). Há uma quarta etapa de avaliação, com vista ao contínuo aperfeiçoamento deste processo. Esta última busca identificar os obstáculos políticos enfrentados no processo de advocacia sanitária (VI), na medida deste trabalho. Antes, porém, é apresentada a metodologia empregada (I) e o caso concreto analisado (II).

\section{METODOLOGIA}

Os métodos utilizados nesse trabalho foram o estudo de caso documental e o método indutivo.

Em um primeiro momento, a partir do estudo de caso, buscou-se apreender o processo de advocacia sanitária em defesa do direito de pesquisa com células-tronco embrionárias, em curso atualmente no Brasil. Procurouse sintetizar os impedimentos políticos à advocacia sanitária, conforme o esquema das quatro etapas do processo de advocacia. Os principais pontos enfocados foram: a exposição detalhada do problema; a identificação do direito reivindicado; o diagnóstico da situação, a partir da identificação dos atores envolvidos, do papel da mídia nesse processo, da análise das diferentes dimensões envolvidas no problema, dos argumentos de ordem jurídica, ético-religiosa e técnico-científica em jogo e da exposição dos principais interesses existentes; a exposição das estratégias da advocacia in casu; e a identificação dos obstáculos políticos ao exercício da advocacia no caso estudado.

Ao final, utilizou-se o método indutivo para construir um roteiro geral de identificação dos óbices políticos, passível de ser aplicado a qualquer processo de advocacia sanitária. A interpretação das fontes documentais, bem como a compreensão do conceito e do processo de advocacia foram possíveis a partir da análise das fontes bibliográficas referidas.

(2) Cf. BARBER-MADDEN, R. La abogacía en salud publica. In: OPS: el derecho a la salud en la nueva constitución brasileña, cit. 1992. p. 19. Ver, ainda: DALLARI, Sueli Gandolfi et al. Advocacia em saúde no Brasil contemporâneo. Revista de Saúde Pública, São Paulo, ano 30, v. 6, p. 596, 1996. 


\section{A PESQUISA COM CÉLULAS-TRONCO EMBRIONÁRIAS E O DIREITO BRASILEIRO}

Em março de 2005, a Lei n. 11.105/05 regulamentou o tema da biossegurança no Brasil e, especialmente, a manipulação genética. Diante do avanço da ciência nesse campo, essa lei foi promulgada para garantir o mínimo ético ${ }^{(3)}$ a ser respeitado pelos cientistas e, especialmente, pelas empresas ligadas à aplicação lucrativa dos saberes científicos.

Em um dos seus dispositivos, a lei de biossegurança estabeleceu os limites em que é possível a pesquisa com células-tronco embrionárias (CTE).

Art. 5o É permitida, para fins de pesquisa e terapia, a utilização de células-tronco embrionárias obtidas de embriões humanos produzidos por fertilização in vitro e não utilizados no respectivo procedimento, atendidas as seguintes condições:

I - sejam embriões inviáveis; ou

II - sejam embriões congelados há 3 (três) anos ou mais, na data da publicação desta Lei, ou que, já congelados na data da publicação desta Lei, depois de completarem 3 (três) anos, contados a partir da data de congelamento.

$\S 1^{\circ} \mathrm{Em}$ qualquer caso, é necessário o consentimento dos genitores.

$\S 2^{\circ}$ Instituições de pesquisa e serviços de saúde que realizem pesquisa ou terapia com células-tronco embrionárias humanas deverão submeter seus projetos à apreciação e aprovação dos respectivos comitês de ética em pesquisa.

$\S$ 3ํ É vedada a comercialização do material biológico a que se refere este artigo e sua prática implica o crime tipificado no art. 15 da Lei $n$. 9.434, de 4 de fevereiro de 1997.

Em novembro de 2005, o Executivo regulamentou a lei de biossegurança. Assim, o Decreto n. 5.591/05 reiterou, nos mesmos termos da referida lei, as possibilidades em que se permite a pesquisa com CTE (art. 63). Além disso, acrescentou outras disposições, como, por exemplo, a que diz que "a utilização, em terapia, de células tronco embrionárias humanas, observado o art. 63, será realizada em conformidade com as diretrizes do Ministério da Saúde para a avaliação de novas tecnologias" (art. 67). Tanto a lei como o decreto conceituam CTE como "células de embrião que apresentam a capa-

(3) Não se pretende afirmar que a teoria do mínimo ético seja fundamento de todo o direito, mas apenas que a lei de biossegurança juridiciza a preocupação ética com a ciência e, nesse sentido, suas disposições têm relação com preceitos morais. Sobre a teoria do mínimo ético, ver: REALE, M. Lições preliminares de direito. 24. ed. São Paulo: Saraiva, 1999. p. 42-44. 
cidade de se transformar em células de qualquer tecido de um organismo" (art. 3ㅜ, XI, Lei n. 11.105/05; art. 3ํ, XII, Decreto n. 5.591/05); essas células são, por isso, no jargão da biologia chamadas totipotentes.

Ocorre que apenas dois meses depois da promulgação da lei de biossegurança - antes mesmo, portanto, do Decreto que a regulamentou - o então Procurador-Geral da República, Claudio Fonteles, provocou o Supremo Tribunal Federal (STF) a decidir sobre a constitucionalidade do art. 5을 lei de biossegurança, antes citado. Trata-se da Ação Direta de Inconstitucionalidade de número 3510 (AD n. 3510).

Fonteles pediu que fosse declarado inconstitucional o art. 5 e parágrafos da Lei n. 11.105/05, porque feriria os dispositivos constitucionais que tratam da dignidade da pessoa humana e do direito à vida (art. 1으. III, e art. 5으, caput). O argumento-chave da inicial é silogístico: a vida e a dignidade são direitos fundamentais; a vida começa com a fecundação; logo, desde a fecundação há direito à vida e à dignidade ${ }^{(4)}$. Aduz, então, argumentos de duas ordens: científica e jurídica. Pela ciência, sustenta que é com a fecundação que a vida tem lugar. Demais, defende que nas pesquisas podem ser utilizadas células-tronco adultas, não havendo necessidade de se utilizar as embrionárias - aqui, aliás, abre-se espaço para um importante juízo de ponderação, a fim de se analisar a proporcionalidade da norma atacada. De ordem jurídica, é o argumento de direito comparado em que é citada a legislação alemã. Jurídico também é o argumento de que utilizar o embrião como meio implica violação do princípio da dignidade humana, o qual impõe que a pessoa humana seja sempre um fim em si mesma, e não um meio para a consecução de outro fim qualquer.

A ADI n. 3510 ainda se encontra em fase de instrução. A sua propositura colocou em xeque os interesses de setores sociais, acadêmicos e de portadores de enfermidades e deficiências, os quais percebem a pesquisa com CTE como um caminho, talvez único, para a solução do mal que lhes aflige. Assim, desenha-se um processo de advocacia em saúde pelos que defendem a constitucionalidade do art. $5^{\circ}$ da lei de biossegurança. Trata-se, sob esta perspectiva, da reivindicação do direito à saúde, constitucionalmente garantido.

$\mathrm{Na}$ outra trincheira, seus antagonistas também possuem argumentos fincados em direitos fundamentais - a vida e a dignidade. Aqui, a advocacia (sempre naquele sentido amplo esclarecido na introdução) é praticada tanto por cientistas contrários ao uso de CTE como pela Igreja Católica, por intermédio da Confederação Nacional dos Bispos do Brasil (CNBB).

(4) A tese central desta petição afirma que a vida humana acontece na, e a partir da, fecundação". AÇÃO DIRETA DE INCONSTITUCIONALIDADE N. 3.510. Petição inicial. Revista Consultor Jurídico, 30 de maio de 2005, Disponível em: <http://conjur.estadao.com.br/static/text/35087,2>. Acesso em: 9 maio 2007. 
Sem dúvida, trata-se do que o direito norte-americano chamaria um hard case, em que ambos os lados assumem posições a priori perfeitamente defensáveis, porque fundadas não em regras distintas, mas, em diferentes valores ${ }^{(5)}$. Não obstante isso, dado que a temática do presente trabalho é a advocacia em saúde, o caso é abordado principalmente sob a perspectiva dos primeiros, ou seja, dos que sustentam a liberdade de pesquisa com CTE como algo necessário à efetivação do direito à saúde.

\section{IDENTIFICAÇÃO DO DIREITO REIVINDICADO}

Do ponto de vista da advocacia sanitária, o direito reivindicado é a liberdade de pesquisa com CTE, nos termos do art. 5ำ da lei de biossegurança, para a efetivação do direito à saúde. Tanto a liberdade de pesquisa como a saúde são direitos fundamentais.

O direito reivindicado fica claro, em primeiro lugar, com a resposta dada à inicial. Em decisão interlocutória de dezembro de 2006, o Ministro Relator Ayres Britto citou os argumentos da Presidência da República e do Congresso Nacional, em prol da constitucionalidade do dispositivo da lei de biossegurança:

A seu turno, e em sede de informações (fls. 82/115), o Presidente da República defende a constitucionalidade do texto impugnado. Isto por entender que, "com fulcro no direito à saúde e no direito de livre expressão da atividade cientifica, a permissão para utilização de material embrionário, em vias de descarte, para fins de pesquisa e terapia, consubstanciam-se em valores amparados constitucionalmente" (sic, fls. 115). A mesma conclusão, aliás, a que chegou o Congresso Nacional (fls. 221/245). ${ }^{(6)}$

Com efeito, a CF/88 erigiu a saúde ao patamar de direito fundamental, seja como direito público subjetivo, seja como dever estatal (direito social). Diz o art. 196 constitucional: "A saúde é direito de todos e dever do Estado, garantido mediante políticas sociais e econômicas que visem à redução do risco de doença e de outros agravos e ao acesso universal e igualitário às ações e serviços para sua promoção, proteção e recuperação."

Ademais, a livre expressão da atividade científica é tutelada constitucionalmente nos direitos individuais. Realmente, o inciso IX do art. 5ํㅜㄹ determina que "é livre a expressão da atividade intelectual, artística, científica

(5) Cf. ALEXY, Robert. Teoría de los derechos fundamentales. Madrid: Centro de Estudios Constitucionales, 1997.

(6) BRASIL. Supremo Tribunal Federal. Min. Ayres Britto. Decisão interlocutória de 19 dez. 2006, publicada no DJ n. 23, de 01 fev. 2007. ADI n. 3.510. Disponível em: <http://www.stf.gov.br>. Acesso em: 9 maio 2007. 
e de comunicação, independentemente de censura ou licença". Não obstante, o STF já reconheceu que as liberdades públicas não são direitos absolutos $^{(7)}$.

Enfim, através do ingresso na lide como amicus curiae ${ }^{(8)}$, o Movimento em Prol da Vida (MOVITAE) reivindica o direito à saúde pela liberdade de pesquisa com CTE. Nessa linha, a ADIn n. 3.510 põe em risco os interesses dos portadores de uma série de doenças, os quais querem que seja garantida a liberdade de pesquisa em CTE. Essas pesquisas são a esperança mais próxima dessas pessoas para alcançarem um melhor nível de saúde e de qualidade de vida. Nesse sentido, entende-se a liberdade de pesquisa como uma garantia, um instrumento, do direito fundamental à saúde.

\section{DIAGNÓSTICO DA SITUAÇÃO(9)}

Como visto na introdução, a segunda etapa do processo de advocacia ocupou-se do diagnóstico da situação, ou seja, da análise das variáveis em jogo, quais sejam: os atores diretamente envolvidos, a mídia, a complexidade do problema (saúde pública, ética, religião), as diferentes ordens de argumentos esgrimidos (jurídicos, ético-religiosos e científicos) e, enfim, os diferentes interesses em jogo.

\section{Atores diretamente envolvidos}

Em 30 de maio de 2005, o então Procurador-Geral da República, Cláudio Fonteles, protocolou a inicial da ADI junto ao STF. O processo, distribuído, recebeu a relatoria do Ministro Ayres Britto. Ator chave no processo, é ele o responsável pela rejeição ou aceitação de cada um dos que postulam a posição de amicus curiae. Por certo, cada um dos onze Ministros do STF desempenharão a função de decidir pela constitucionalidade, ou não, do art. $5^{\circ}$ da lei de biossegurança. Assim, aquele que atua pela reivindicação do direito deve considerar as diferentes posições dos magistrados acerca da questão, ou de questões próximas.

(7) HC 82.424, julgado em 17 de setembro de 2003.

(8) Amicus curiae são admitidos, em sede de ADI, nos termos do $\S 2^{\circ}$ do art. $7^{\circ}$ da Lei n. 9.868/99: "O relator, considerando a relevância da matéria e a representatividade dos postulantes, poderá, por despacho irrecorrível, admitir, observado o prazo fixado no parágrafo anterior, a manifestação de outros órgãos ou entidades." (grifado).

(9) Nota do Editor: No dia 5 de março a Ação Direta de Inconstitucionalidade (ADI n. 3.510) ainda não havia sido julgada no Supremo Tribunal Federal. Nesse dia, o ministro Carlos Ayres Britto, relator da ação, a julgou improcedente, tendo defendido as pesquisas com células-tronco embrionárias. A presente edição da Revista de Direito Sanitário foi encaminhada para publicação em 6 de março de 2008. 
Em 28 de novembro de 2005, o Ministro Ayres Britto, deferiu o pedido do Movimento em Prol da Vida (MOVITAE) ${ }^{(10)}$, para integrar o processo como amicus curiae. Em sucinta decisão, o Ministro Relator considerou a importância da matéria e a representatividade da postulante ${ }^{(11)}$. Mais tarde, foram deferidas iguais participações ao Instituto de Bioética, Direitos Humanos e Gênero (ANIS) ${ }^{(12)}$ e à Confederação Nacional dos Bispos do Brasil $(\mathrm{CNBB})^{(13)}$. As entidades MOVITAE ${ }^{(14)}$ e a ANIS $^{(15)}$ tornaram-se protagonistas da reivindicação pela liberdade de pesquisa com células-tronco, posicionando-se pela constitucionalidade do art. $5^{\circ}$ da lei de biossegurança, em nome do direito à saúde e, por extensão, à própria vida. Diferentemente, a $\mathrm{CNBB}^{(16)}$ acrescentou ingredientes religiosos ao debate democrático, defendendo a inconstitucionalidade da norma, em nome do direito à vida e da dignidade do embrião humano.

Um cidadão chamado Reginaldo da Luz Ghisolfi requereu participação como amicus curiae. No entanto, em 3 de maio de 2006, seu pedido foi indeferido pelo Ministro Relator ${ }^{(17)}$, precisamente por lhe faltar a representatividade necessária para a intervenção como interessado. Embora o cidadão tenha sustentado ser estudioso da matéria, o Relator, interpretando o art. $7^{\circ}$, $\S 2^{\circ}$, da Lei n. 9.868/99, não considerou suficiente a condição individual do requerente, sendo necessária sua qualidade de representante de uma coletividade. Ou seja, o critério para a participação na discussão não foi técnico, mas político - atende ao princípio democrático. Aqui já é possível perceber um obstáculo à advocacia sanitária.

(10) A MOVITAE "conta com o apoio institucional de Associação de Diabetes Juvenil — ADJ, Grupo de Abordagem Multidiciplinar da Terapia de Esclerose Múltipla - MULTIPLEM, Associação Brasil Parkinson e Associação Brasileira de Distrofia Muscular - ABDIM". Ver: AÇÃO DIRETA DE INCONSTITUCIONALIDADE N. 3.510. Pedido de ingresso como amicus curiae formulado por MOVITAE - Movimento em Prol da Vida. Revista Consultor Jurídico, 9 de outubro de 2005. Disponível em: <http://conjur.estadao.com.br//static/text/38560,1>. Acesso em: 9 maio 2007.

(11) BRASIL. Supremo Tribunal Federal. Min. Ayres Britto. Decisão interlocutória de 28 de novembro de 2005, publicada no DJ n. 240, de 15 de dezembro de 2005. In: ADI n. 3.510. Disponível em: www.stf.org.br. Acesso em: 9 maio 2007.

(12) BRASIL. Supremo Tribunal Federal. Min. Ayres Britto. Decisão interlocutória de 28 nov. 2005, publicada no DJ n. 240, de 15 dez. 2005. ADI n. 3.510. Disponível em: <http://www.stf.gov.br>. Acesso em: 9 maio 2007.

(13) BRASIL. Supremo Tribunal Federal. Min. Ayres Britto. Decisão interlocutória de 17 abr. 2007, publicada no DJ n. 77, de 23 abr. 2007. ADI n. 3.510. Disponível em: <http://www.stf.gov.br>. Acesso em: 9 maio 2007.

(14) Ver: MOVITAE - Movimento em Prol da Vida. Disponível em: <www.movitae.bio.br>.

(15) Ver: INSTITUTO DE BIOÉTICA, DIREITOS HUMANOS E GÊNERO. Disponível em: $<w w w$.anis.org.br>.

(16) Ver: CONFERÊNCIA NACIONAL DOS BISPOS NO BRASIL. Disponível em: <www.cnbb.org.br>. (17) BRASIL. Supremo Tribunal Federal. Min. Ayres Britto. Decisão interlocutória de 3 maio 2006, publicada no DJ n. 89, de 11 maio 2007. In: $A D I$ n. 3.510. Disponível em: <http://www.stf.gov.br>. Acesso em: 9 maio 2007. 
Em dezembro de 2006, o Relator determinou a realização de audiência pública ${ }^{(18)}$, a fim de promover a participação social e, assim, dar maior legitimidade à decisão do STF. A audiência ocorreu em 20 de abril de 2007 e contou com a participação de cientistas que tanto propugnaram pela liberdade de pesquisa com células-tronco, como também corroboraram os argumentos em prol da inconstitucionalidade do art. 5ㅇ da lei de biossegurança. A audiência acolheu a sociedade, que se fez presente seja na figura dos cadeirantes, que têm nas pesquisas sua esperança de melhora, seja na figura dos membros da CNBB, que argumentam em nome da ciência, mas inevitavelmente de acordo com o pensamento da Igreja. Enfim, com a audiência, os membros da comunidade científica tornaram-se atores no espaço político do debate em torno da constitucionalidade da pesquisa com CTE.

Muitas foram as repercussões desta audiência; mas, merece destaque uma delas, em especial. Trata-se do Manifesto da Federação das Sociedades de Biologia Experimental (FeSBE), de 27 de abril de 2007, amplamente divulgado, em prol da constitucionalidade da norma que permite a pesquisa com CTE. Do contrário, haveria "danos irreparáveis à geração de conhecimento em nosso país"(19).

Tudo isso demonstra que a discussão toma a sociedade, de maneira que o STF, como tribunal político que é, não pode deixar de considerar todos os elementos presentes no debate. Essa multiplicidade de atores é, sem dúvida, positiva, porque é vivência democrática. Todavia, também é certo que a democracia é desafiadora aos homens públicos, aos detentores do poder decisório, porque exige deles que ajam legitimamente. Aqui, mais um obstáculo político se apresenta, trata-se da dificuldade de articulação entre os atores difusos de um processo social de grandes proporções. Um bom obstáculo, porque inerente e essencial à democracia.

\section{O papel da mídia}

Dado o proeminente papel da mídia como formadora da opinião pública no país, faz-se importante apontar seu posicionamento nessa discussão, principalmente em um contexto político no qual setores sociais foram chamados a expor suas opiniões e divergências. Cabe destacar que a abordagem

(18) Com isso, aplicou-se pela primeira vez essa possibilidade no expediente do STF art. $9^{\circ}$, $\S 1^{\circ}$, Lei n. 9.868/99. Diante da ausência de regra, no regimento do Tribunal, para a condução de audiências públicas, o Ministro Ayres Britto decidiu aplicar, por analogia, as disposições do Regimento Interno da Câmara dos Deputados, arts. 255 a 258, considerando a relevância dada pela Constituição às audiências públicas art. $58, \S 2^{\circ}$, inciso II, CF/88.

(19) FEDERAÇÃO DAS SOCIEDADES DE BIOLOGIA EXPERIMENTAL. Manifesto sobre pesquisa com células-tronco. Disponível em: <http://www.fesbe.org.br/download/manifesto_cel_tronco_stevens.doc>. Acesso em: 26 maio 2007. 
midiática dada ao tema aqui enfocado não é unânime, em razão da multiplicidade de veículos (e de interesses) existentes. Por isso, procederemos a uma pequena análise de notícias veiculadas em jornais de grande circulação (que veiculam suas notícias também no formato online).

No ano de 2004, após a aprovação da lei de biossegurança na Câmara dos Deputados, enquanto ela tramitava no Senado, a mídia, de uma forma geral, posicionou-se a favor da aprovação da pesquisa com embriões. Publicou matérias nas quais explicava a "polêmica" sobre as CTE, já assinalando o problema ético que a mesma representava, principalmente pelo fato de colocar em disputa cientistas e religiosos. Quanto ao conteúdo, muitas das matérias mostraram as pesquisas com CTE como a "esperança para os portadores de doenças genéticas"(20), destacando a opinião de políticos e pesquisadores, enfatizando suas possibilidades promissoras.

As reportagens mais recentes já trazem para o debate a convocação da audiência pública pelo STF. Jornais como O Globo, a Folha de S. Paulo e - Estado de São Paulo apresentam argumentos contra e a favor da pesquisa com CTE. No lado dos argumentos contrários, geralmente, sublinha-se a ligação dos defensores da inconstitucionalidade da lei com a Igreja Católica. Em reportagem do jornal $O$ Globo: "lobby mais forte tem sido realizado pela Conferência Nacional de Bispos do Brasil. A entidade é representada na causa por dois dos mais renomados juristas do país: Ives Gandra Martins numerário da Opus Dei, um grupo radical da Igreja Católica - e Francisco Rezek, ministro aposentado do STF"(21). Além disso, o jornal Folha de S. Paulo destacou a realização da audiência pública, como um provável "debate científico sem sentido"(22) que colocaria em cena uma batalha entre religiosos e laicos. Pode-se dizer que nesta mesma matéria, o autor posicinou-se, indiretamente, a favor das pesquisas, ao explicitar em que consistia o dispositivo da lei de biosegurança e explicar qual é o destino dos embriões congelados há mais de três anos nas clínicas de fertilização in vitro: "ir para o lixo".

De uma forma geral, considera-se que a mídia vem cumprindo seu papel informativo e educativo, ao fornecer dados sobre ambos os lados da questão. Contudo, constata-se também certa tendência a uma exploração de cunho sensacionalista do tema, quando assuntos polêmicos como a questão das CTE são relacionados a outras temáticas que igualmente produzem

(20) CÉLULAS-TRONCO são esperança para portadores de doenças genéticas. Folha de S. Paulo, 13 mar. 2004. Disponível em: <http://www1.folha.uol.com.br/folha/ciencia/ult306u11307.shtml>. Acesso em 20 maio 2007.

(21) PESQUISAS com células-tronco dividem especialistas no STF. O Globo, 20 abr. 2007. Disponível em: <http://oglobo.globo.com/ciencia/mat/2007/04/20/295442915.asp>. Acesso em: 28 maio 2007.

(22) SUPREMO Tribunal Federal tenta definir o início da vida. Folha de S. Paulo, 20 abr. 2007. Disponível em: <http://www.1.folha.uol.com.br/folha/ciencia/ult306u16321.shtml>. Acesso em 27 maio 2007. 
divergências declaradas entre ciência e religião e, portanto, aumentam o interesse do público, tais como, por exemplo, a legalização do aborto ambos temas explorados à exaustão quando da visita do pontífice da Igreja Católica ao Brasil.

\section{Dimensões do problema: saúde pública, ética, religião}

O diagnóstico para a advocacia sanitária, além de identificar os atores diferentes envolvidos, precisa situar o problema no seu contexto social. No caso em tela, percebe-se que se trata de uma questão que envolve, pelo menos, três dimensões.

Trata-se, sem dúvida, de um problema de saúde pública, visto que a CTE, por ser totipotente, pode, em tese, desenvolver-se em qualquer um dos tecidos que compõem o corpo humano. Ou seja, a pesquisa com as CTE pode vir a permitir a cura, ou ao menos significativa melhora, para os portadores de uma imensa gama de enfermidades, por exemplo, os portadores de esclerose múltipla e os paraplégicos.

Além disso, há uma inafastável dimensão ética, pertinente tanto à ciência como à religião. No que atine à ética científica, trata-se do problema dos limites à manipulação da vida humana. A existência de CTE congeladas já é uma conseqüência da reprodução assistida, da fertilização in vitro. A sua utilização médica é uma nova perspectiva que acena para boas, mas também para nefastas, perspectivas. O uso de CTE também se relaciona com a clonagem terapêutica ou reprodutiva, temas ainda mais polêmicos. Certo é que a ciência não pode avançar a qualquer custo, violando a dignidade humana e que não conhece oposições duradouras, se impondo pelos fatos. O problema passa a ser, então, o da regulação do uso da tecnologia. O art. 5은 da lei de biossegurança é discutido, então, nesses termos - é essa a regulação correta, ou essa regulação viola a Constituição? De qualquer sorte, um problema central do mundo globalizado, maior do que em tempos precedentes, diz respeito à necessidade de que ao avanço da técnica corresponda um avanço na ética ${ }^{(23)}$.

Finalmente, na sua dimensão religiosa, que também é ética, o problema diz respeito ao que a sociedade brasileira pensa sobre o assunto e à influência social da Igreja Católica em nosso país. Coloca-se, então, o problema da relação entre Igreja e Estado. O Estado brasileiro é laico, mas a sociedade, em boa medida, não o é. Certamente, o Estado deve tomar suas decisões independentemente da posição da Igreja; por outro lado, não as pode tomar contra o que quiser o povo, que é constitucionalmente soberano.

(23) Cf. COMPARATO, Fábio Konder. Ética: direito, moral e religião no mundo moderno. São Paulo: Companhia das Letras, 2006. 
Enfim, também cabe recordar que não se sabe o que a maioria da população brasileira pensa sobre a pesquisa com CTE. Ademais, por vezes é o interesse da minoria que é tutelado pela democracia, não o da maioria. Essas diferentes perspectivas pelas quais se pode enfrentar o problema se traduzem em inúmeros argumentos favoráveis, ou não, à pesquisa com CTE.

\section{Argumentos de ordem jurídica, ética (religiosa) e técnico-científica}

Dada a complexidade do problema político da pesquisa com CTE, podem ser identificados, ao menos, argumentos de três ordens: jurídica, ético-religiosa e técnico-científica.

Juridicamente, o Procurador da República, na inicial da ADI n. 3.510, alegou que 0 art. 5으 da lei de biossegurança violaria o direito à vida (caput do art. $5^{\circ}$ ) e a dignidade humana (art. 1으. III), ambos constitucionalmente assegurados. Este argumento tem como premissa que a vida começa com a concepção, como visto supra.

A este argumento opõe-se, também na esfera jurídica, o argumento de que os portadores de certas doenças, como a esclerose múltipla, têm direito à saúde e que a pesquisa científica é o meio para a efetividade desse direito, sendo que tanto a saúde como a liberdade de pesquisa também são direitos constitucionalmente garantidos (arts. 6ำ e 5, IX, respectivamente). Além disso, argumenta-se que a lei de biossegurança é criteriosa, permitindo a pesquisa com CTE dentro de estritos limites, que ela própria determina.

A Lei permite a realização de pesquisas com células extraídas de embriões, mas exige que:

a) os embriões tenham resultado de tratamentos de fertilização in vitro (art. 5o, caput);

b) os embriões sejam inviáveis (art. 5ำ I) ou que não tenham sido implantados no respectivo procedimento de fertilização, estando congelados há mais de três anos (art. 5을 II);

c) os genitores dêem seu consentimento (art. 5으 $\S 1^{\circ}$ );

d) a pesquisa seja aprovada pelo comitê de ética da instituição (art. 5ํㅡ, $\left.\S 2^{\circ}\right)$.

9. Além disso, a Lei n. 11.105/2005, proíbe:

a) a comercialização de embriões, células ou tecidos (art. 5ำ § 3o e Lei

n. 9.434/97, art. 15)[7];

b) a clonagem humana (art. $6^{\circ}$, IV)[8]; e 
c) a engenharia genética em célula germinal humana, zigoto humano e embrião humano (art. $6^{\circ}$, III)[9]. ${ }^{(24)}$

Em segundo lugar, há argumentos éticos. Pela inconstitucionalidade do art. $5^{\circ}$ da lei de biossegurança, afirma-se que ele permitiria uma cruel distinção: uns seres humanos seriam mais "valiosos", outros (os embriões humanos) seriam menos. Argumenta-se que tal distinção fere frontalmente o valor da dignidade humana.

Pela constitucionalidade do dispositivo citado, sustenta-se ${ }^{(25)}$ que ele não viola preceitos éticos, uma vez que é acompanhado de regras que proíbem condutas anti-éticas, como a clonagem humana e a comercialização de material biológico. Além disso, os termos da lei de biossegurança respeitariam os princípios éticos da autonomia, da beneficência e da justiça.

Em grande medida, os argumentos de ordem ética contrários à pesquisa com CTE são endossados pela autoridade da Igreja Católica. Um fato político relevante foi a recente vinda ao Brasil do pontífice romano, incisivo ao defender uma postura conservadora com relação a diversos temas além do uso de embriões, o aborto, entre outros. Curiosamente, no seio da própria comunidade católica têm tido voz posicionamentos discordantes a essa postura conservadora - veja-se, por exemplo, o movimento das Católicas pelo direito de decidir(26), que advoga pela descriminalização do aborto.

Em terceiro lugar, sob o prisma da ciência, há pelo menos dois argumentos que atestam a inconstitucionalidade ${ }^{(27)}$ do art. $5^{\circ}$ da lei de biossegurança. O primeiro é o que diz que a vida começa com a concepção. O segundo é o que afirma a possibilidade de utilização de células-tronco adultas, sem prejuízo para a medicina, em comparação com as CTE.

Ambos os argumentos são refutados por outros, igualmente científicos. Primeiro, porque além da tese de que a vida começa com a concepção, há teses de que ela começaria com a nidação ou com a formação do sistema nervoso central, entre outras. Ademais, quanto à utilização de célulastronco adultas, argumenta-se que sua utilidade seria limitada, pois estas células não possuem capacidade de se transformarem em qualquer tecido que compõe o corpo humano. Esta propriedade apenas pode ser vista nas CTE, por serem totipotentes.

15. As características que singularizam as células-tronco em relação às demais células são: a) a capacidade de se diferenciarem, i. e., de se converterem em distintos tecidos no organismo; e b) a propriedade de auto-

(24) AÇÃO DIRETA DE INCONSTITUCIONALIDADE N. 3.510. Pedido de ingresso como amicus curiae formulado por MOVITAE - Movimento em Prol da Vida, cit.

(25) Id. Ibid.

(26) Ver: CATÓLICAS PELO DIREITO DE DECIDIR. Disponível em: <www.catolicasonline.org.br>.

(27) AÇÃO DIRETA DE INCONSTITUCIONALIDADE N. 3.510. Petição inicial, cit. 
replicação, isto é, a capacidade que têm de produzirem cópias idênticas de si mesmas. Todavia, tais características não se manifestam com a mesma intensidade em todas as células-tronco. Estas podem ser classificadas em: a) totipotentes, as quais possuem a capacidade de se diferenciar em qualquer dos 216 tecidos que compõem o corpo humano; b) pluripotentes ou multipotentes, que podem se diferenciar em quase todos os tecidos, menos na placenta e nos anexos embrionários; c) oligopotentes, que são capazes de se diferenciar em poucos tecidos; ou d) unipotentes, que só conseguem se diferenciar em um único tecido.

16. As totipotentes e as pluripotentes somente são encontradas nos embriões (por isso, são chamadas de embrionárias). Tais células podem ser extraídas até três semanas após a fecundação (aproximadamente 14 dias). É essa capacidade de se diferenciar em todas as células do organismo humano que faz com que as células-tronco embrionárias se tornem necessárias para a pesquisa médica. Como as células-tronco adultas são apenas oligopotentes ou unipotentes, o seu potencial para a pesquisa é significativamente menor, embora também sejam dotadas de importância ${ }^{(28)}$.

Conhecer os argumentos da disputa é um elemento central do diagnóstico, no processo de advocacia em saúde. No entanto, isso não é o bastante. É importante saber que existem distintos interesses em jogo e que para cada um é possível tecer argumentos diversos. A seguir são referidos alguns dos possíveis interesses em questão no caso da pesquisa com CTE.

\section{Interesses envolvidos}

Os primeiros interessados na pesquisa com CTE são os portadores de doenças degenerativas que depositam aí suas esperanças de melhora. Trata-se de um interesse particular, se cada um deles for considerado individualmente. Mas, também se trata de um interesse coletivo e legitimado pelas ONG que atuam em sua defesa. Algumas dessas entidades, como visto, alcançaram a condição de amicus curiae na ADI n. 3.510. No entanto, seria ingênuo o diagnóstico que não percebesse interesses mais pragmáticos nesse processo de advocacia, como o das organizações da sociedade civil em serem reconhecidas como legítimas mandatárias dos primeiros interessados. Disso depende não apenas o sucesso da atuação destas entidades, mas também a sua própria existência.

Outro interesse em jogo é o dos laboratórios e centros de pesquisa que seriam economicamente prejudicados com a decretação de inconstitu-

(28) AÇÃO DIRETA DE INCONSTITUCIONALIDADE N. 3.510. Pedido de ingresso como amicus curiae formulado por MOVITAE - Movimento em Prol da Vida, cit. 
cionalidade do art. 5ำ da Lei de Biossegurança, pois se veriam impedidos de atuar no Brasil. O poder econômico deste segmento é um elemento que não pode ser negligenciado.

Ademais, há o governo que, em nome de um interesse nacional, quer que este nicho tecnológico permaneça no Brasil e que pesquisas com CTE sejam levadas a efeito por centros de pesquisa nacionais, promovendo a participação e formação de recursos humanos nacionais qualificados. Seguramente, uma eventual decretação de inconstitucionalidade faria com que a pesquisa com CTE migrasse para países de legislação mais progressista, com a conseqüente fuga de "cérebros" nacionais.

Em outra trincheira, tem-se a Igreja Católica que busca manter sua tradição moral e sua influência na sociedade brasileira. Via de regra, em temas que tocam a autonomia da pessoa (disposição de CTE provenientes de fertilização in vitro, aborto, sexo fora do casamento etc.) a instituição apresenta normas de conduta que garantam sua posição privilegiada de centro e normalizadora das relações sociais. Não obstante, não se pode negligenciar o discurso católico o qual assenta-se em uma tradição secular.

\section{ESTRATÉGIAS DA ADVOCACIA IN CASU}

Partindo do pressuposto de que "a advocacia em saúde não se ocupa do direito à saúde propriamente dito, mas da sua realização em contextos localizados"(29) e de que sempre se trata de um objetivo específico, muito bem definido, são necessárias táticas igualmente precisas para atingir esse fim.

\section{Objetivo final}

No caso ora analisado, o objetivo final da advocacia em saúde é convencer os Ministros dos STF de que o art. 5으 da lei de biossegurança é constitucional. Em outros termos, significa conseguir a manutenção da legalidade da pesquisa com CTE, nos termos da lei vigente. Assim, busca-se afastar o perigo de retrocesso legal, representado pela propositura da ADI n. 3.510.

\section{Passos de ação}

Uma vez que se tenha uma finalidade precisa, as táticas precisam ser muito bem determinadas; as variáveis, muito bem conhecidas. Não se faz advocacia "em geral"; bem ao contrário, ela é sempre concreta e, como visto,

(29) DALLARI, Sueli Gandolfi et al. Advocacia em saúde no Brasil contemporâneo, cit., p. 597. 
visa a um objetivo específico. A análise do caso da pesquisa com CTE permite a esquematização de alguns desses passos.

O primeiro passo talvez seja o de congregar os interessados em um órgão mais forte, legitimado a agir em nome deles. Trata-se de constituir uma ONG, ou ingressar em uma. Mesmo diferentes ONGs podem unir-se em entidades de maior representatividade. No caso em tela, tem-se a MOVITAE e a ANIS, pela constitucionalidade do art. 5을 la lei; e a CNBB, pela sua inconstitucionalidade.

Aqui já se verifica um possível obstáculo que é de conseguir essa legitimidade, ou pelo menos de participar desse movimento. Alguém que resida em uma pequena cidade poderá ter maiores dificuldades do que o domiciliado em um grande centro. Igualmente, as ONGs em grandes cidades costumam ter maior atuação.

Uma vez fazendo parte de uma entidade representativa, é preciso agir para ingressar na arena política. No caso sob análise, as ONGs postularam sua intervenção como amicus curiae no processo da ADI n. 3.510. Este pedido é analisado criteriosamente e, como visto, caso não se faça prova da representatividade de um setor social interessado, será indeferido.

A atuação como amicus curiae parece ser mais eficiente, porque se dá dentro da arena decisória. No entanto, também é possível agir fora do centro de decisão, como fez a FeSBE com o seu manifesto. Este tipo de ação, embora tenha grande potencialidade de alcance, parece ser menos eficiente do que a atuação diante daqueles que decidirão a questão.

Estando em cena, o outro passo da advocacia é fazer-se ouvir. Seja por manifestação nos autos, seja pela participação na audiência pública, viu-se que esse passo foi seguido in casu. Além disso, é importante fazer-se ouvir pela mídia. Quanto a isso, viu-se que a imprensa deu amplo espaço para que os argumentos se tornassem públicos. Um possível obstáculo, aqui, pode ser uma má repercussão social das notícias, ou antes, a dificuldade de conseguir espaço nos meios de comunicação.

Quanto mais se conseguir mobilizar e informar a população, melhor para o processo de advocacia política. Em um Estado Democrático de Direito, a sociedade civil tende a ter um papel preponderante para o convencimento da autoridade pública.

\section{OBSTÁCULOS POLÍTICOS À ADVOCACIA}

A advocacia pela saúde, no caso ora analisado, é essencialmente política. Embora se ocupe, in casu, da constitucionalidade de uma lei (e bem por isso), o STF é um foro político de relevância equiparável ao Legislativo e ao Executivo. Não apenas a teoria da separação e interde- 
pendência entre os Três Poderes, mas também a realidade política inerente à prestação jurisdicional( ${ }^{(30)}$ permitem tal afirmação.

Considerando o objetivo deste trabalho, de identificar alguns dos obstáculos políticos antepostos à advocacia sanitária, tem-se que o impedimento inicial é a reunião dos interessados no resultado do processo de advocacia sanitária. A junção das pessoas que venham a ser diretamente beneficiadas é crucial porque a advocacia, nesse caso, se faz em prol de uma coletividade. Assim, podem ser enfrentadas dificuldades quanto ao ingresso em uma ONG, ou mesmo quanto à constituição de uma. Esse problema pode ser menor nos grandes centros urbanos, mas pode ser decisivo tratando-se de cidadãos que vivam em cidades de interior, ou na zona rural.

Percebeu-se um exemplo claro deste obstáculo na decisão do Ministro Ayres de Britto, negando a um cidadão, pesquisador do assunto, ingressar, individualmente, como amicus curiae na ADI n. 3.510. Precisamente, faltouIhe representatividade.

Outro óbice é a dificuldade de conseguir espaço nos meios de comunicação, de conseguir informar à população sobre a importância da questão e da ação de advocacia. Ainda que se tenha acesso à mídia, pode-se ter problemas com eventuais repercussões negativas do processo de advocacia.

É fundamental, nesse ponto, que se conquiste a adesão de aliados. É importante que haja constante diálogo entre os membros das ONGs, da Academia, dos setores público e privado e da mídia. Dada a complexidade da advocacia política, é importante contar com o apoio de diferentes setores e trabalhar em rede. Com isso, poder-se-á dispor de argumentos científicos.

Ocorre que a existência de argumentos científicos implica que a decisão política deverá considerar o posicionamento dos pesquisadores. Ainda que sejam dissonantes os posicionamentos dos cientistas - o que restou evidente após a audiência pública do processo da ADI n. 3.510 - eles informarão a decisão final. Isso implica alguns obstáculos específicos.

Por exemplo, para refutar esses argumentos científicos, virão outros, contrários, mas, possivelmente, também respaldados na ciência. O problema aqui, se transfere para o órgão que tomará a decisão final, que terá um desafio a superar. Com efeito, "a opção política recebe hoje a influência direta da técnica. [...] As grandes escolhas dependem forçosamente do parecer técnico de maneira que a margem para a decisão puramente política se torna reduzida"(31).

Enfim, outro obstáculo que existe no caso de advocacia sanitária em defesa da liberdade de pesquisa — ou seja, em defesa da constitucionalidade

(30) Cf. DALLARI, Dalmo de A. O poder dos juízes. São Paulo: Saraiva, 1996.

(31) TELLES, Maria E. R. da S. Grupos de pressão e regime representativo. São Paulo: IBEP, 1988. 
do art. 5 da lei de biossegurança — está na relação entre o Estado e a Igreja Católica. A partir da participação ativa da CNBB e da visita oficial do pontífice romano ao Brasil, a Igreja ocupou um espaço relevante no cenário político do caso. Embora não tenha nenhum poder decisório, ela tem o condão de influenciar grandes parcelas da sociedade e, talvez, dos julgadores. Assim, seria importante sensibilizar os católicos para a importância da pesquisa com CTE e para o fato de que o art. 5ํㅡ da lei atacada não é uma "carta em branco"; pelo contrário, traz uma regulação criteriosa dos limites em que se permite tal prática.

\section{CONSIDERAÇÕES FINAIS}

Após a análise do processo de advocacia sanitária pela liberdade de pesquisa com CTE, partiu-se, por indução, para um esboço do que pode vir a ser um quadro de identificação de obstáculos políticos à advocacia sanitária em geral.

\section{Quadro I}

\begin{tabular}{|c|c|c|}
\hline $\begin{array}{l}\text { Fases do } \\
\text { processo de } \\
\text { advocacia }\end{array}$ & $\begin{array}{l}\text { Ações de } \\
\text { advocacia }\end{array}$ & Possíveis obstáculos \\
\hline $\begin{array}{l}\text { Identificação } \\
\text { do objeto }\end{array}$ & $\begin{array}{l}\text { Delimitação precisa do } \\
\text { campo de ação }\end{array}$ & $\begin{array}{l}\text { Problemas complexos: dimen- } \\
\text { sões jurídica, econômica, cultural, } \\
\text { religiosa, científica etc. }\end{array}$ \\
\hline \multirow{7}{*}{ Diagnóstico da situação } & \multirow{2}{*}{$\begin{array}{l}\text { Identificação dos } \\
\text { atores envolvidos }\end{array}$} & $\begin{array}{c}\text { Bagagem cultural e, eventualmen- } \\
\text { te, religiosa, dos tomadores da } \\
\text { decisão }\end{array}$ \\
\hline & & $\begin{array}{l}\text { Multiplicidade de atores. Dificuldade } \\
\text { de conhecer o posicionamento } \\
\text { preciso de cada um. }\end{array}$ \\
\hline & \multirow{3}{*}{ Exposição na mídia } & $\begin{array}{l}\text { Fazer-se ouvir pelos meios de } \\
\text { comunicação }\end{array}$ \\
\hline & & $\begin{array}{l}\text { Repercussão negativa das } \\
\text { notícias veiculadas }\end{array}$ \\
\hline & & \begin{tabular}{|c|} 
Posicionamento defendido \\
abertamente por um determinado \\
meio de comunicação
\end{tabular} \\
\hline & \multirow{2}{*}{ Interesses conflitantes } & $\begin{array}{c}\text { Oposição de setores econômi- } \\
\text { cos relevantes }\end{array}$ \\
\hline & & $\begin{array}{c}\text { Oposição de setores conserva- } \\
\text { dores da sociedade, como a } \\
\text { Igreja Católica }\end{array}$ \\
\hline
\end{tabular}




\begin{tabular}{|c|c|c|}
\hline $\begin{array}{l}\text { Fases do } \\
\text { processo de } \\
\text { advocacia }\end{array}$ & $\begin{array}{l}\text { Ações de } \\
\text { advocacia }\end{array}$ & Possíveis obstáculos \\
\hline \multirow{6}{*}{ Passos da ação política } & \multirow{3}{*}{$\begin{array}{l}\text { Reunião dos } \\
\text { Interessados }\end{array}$} & $\begin{array}{l}\text { Para o indivíduo, participar do } \\
\text { movimento }\end{array}$ \\
\hline & & $\begin{array}{c}\text { Para a ONG, alcançar legitimidade } \\
\text { e representatividade junto à } \\
\text { sociedade civil }\end{array}$ \\
\hline & & $\begin{array}{c}\text { Constituição de ONG em locais } \\
\text { menos populosos ou interioranos. } \\
\text { As ONGs em grandes cidades } \\
\text { costumam ter maior atuação } \\
\text { política }\end{array}$ \\
\hline & \multirow{2}{*}{$\begin{array}{l}\text { Uso de instrumentos } \\
\text { jurídicos }\end{array}$} & $\begin{array}{l}\text { Recursos humanos qualificados } \\
\text { (advogados em sentido estrito) }\end{array}$ \\
\hline & & Formalismo processual \\
\hline & $\begin{array}{l}\text { Convencimento do } \\
\text { interlocutor }\end{array}$ & $\begin{array}{l}\text { Preponderância de discussões } \\
\text { técnicas e o papel político da } \\
\text { comunidade científica }\end{array}$ \\
\hline
\end{tabular}

Este quadro sintetiza o que foi observado durante a pesquisa e não pretende ser um definitivo, tampouco completo. Por fim, resta dizer que a tentativa de oferecer soluções aos possíveis obstáculos ora apresentados fugiria aos objetivos e às limitações dessa empreitada.

\section{REFERÊNCIAS BIBLIOGRÁFICAS}

AÇÃO DIRETA DE INCONSTITUCIONALIDADE N. 3.510. Pedido de ingresso como amicus curiae formulado por MOVITAE - Movimento em Prol da Vida. Revista Consultor Jurídico, 9 de outubro de 2005. Disponível em: <http:// conjur.estadao.com.br//static/text/38560,1>. Acesso em: 9 maio 2007.

AÇÃO DIRETA DE INCONSTITUCIONALIDADE N. 3.510. Petição inicial. Revista Consultor Jurídico, 30 de maio de 2005, disponível em: <http:// conjur.estadao.com.br/static/text/35087,2>. Acesso em: 9 maio 2007.

ALEXY, Robert. Teoría de los derechos fundamentales. Madrid: Centro de Estudios Constitucionales, 1997.

BARBER-MADDEN, R. La abogacía en salud publica. In: OPS: el derecho a la salud en la nueva constitución brasileña. Washington: OPS, 1992. p. 19-21.

BRASIL. Supremo Tribunal Federal. Constituição Federal e Jurisprudência. Disponível em: <http://www.stf.gov.br/legislacao/constituicao/pesquisa/ constituicao.asp>. Acesso em: 24 maio 2007. 
Min. Ayres Britto. Decisão interlocutória de 3 maio 2006, publicada no DJ n. 89, de 11 maio 2007. In: $A D I$ n. 3.510. Disponível em: <http://www.stf.gov.br>. Acesso em: 9 maio 2007.

Min. Ayres Britto. Decisão interlocutória de 17 abr. 2007, publicada no DJ n. 77, de 23 abr. 2007. ADI n. 3.510. Disponível em: <http:// www.stf.gov.br>. Acesso em: 9 maio 2007.

Min. Ayres Britto. Decisão interlocutória de 19 dez. 2006, publicada no DJ n. 23, de 1 fev. 2007. ADI n. 3.510. Disponível em: <http:// www.stf.gov.br>. Acesso em: 09 maio 2007.

Min. Ayres Britto. Decisão interlocutória de 19 mar. 2007, publicada no DJ n. 57, de 23 mar. 2007. ADI n. 3.510. Disponível em: <http:/ /www.stf.gov.br>. Acesso em: 9 maio 2007.

Min. Ayres Britto. Decisão interlocutória de 28 nov. 2005,

publicada no DJ n. 240, de 15 dez. 2005. ADI n. 3.510. Disponível em: <http:/ /www.stf.gov.br>. Acesso em: 9 maio 2007.

CATÓLICAS PELO DIREITO DE DECIDIR. Disponível em: <www.catolicas online.org.br>.

CÉLULAS-TRONCO são esperança para portadores de doenças genéticas. Folha de S.Paulo, 13 mar. 2004. Disponível em: <http://www1.folha.uol.com.br/ folha/ciencia/ult306u11307.shtml>. Acesso em 20 maio 2007.

COMPARATO, Fábio Konder. Ética: direito, moral e religião no mundo moderno. São Paulo: Companhia das Letras, 2006.

CONFERÊNCIA NACIONAL DOS BISPOS NO BRASIL. Disponível em: $<w w w . c n b b . o r g . b r>$.

DALLARI, Dalmo de A. O poder dos juízes. São Paulo: Saraiva, 1996.

DALLARI, Sueli Gandolfi. El derecho a la salud en la nueva constitución brasileña. In: OPS: el derecho a la salud en la nueva constitución brasileña. Washington: OPS, 1992. p. 11-17.

et al. Advocacia em saúde no Brasil contemporâneo. Revista de Saúde Pública, São Paulo, ano 30, v. 6, p. 592-601, 1996.

FEDERAÇÃO DAS SOCIEDADES DE BIOLOGIA EXPERIMENTAL. Manifesto sobre pesquisa com células-tronco. Disponível em: <http://www.fesbe.org.br/ download/manifesto_cel_tronco_stevens.doc>. Acesso em: 26 maio 2007.

INSTITUTO DE BIOÉTICA, DIREITOS HUMANOS E GÊNERO. Disponível em: $<$ <ww.anis.org.br>.

MOVITAE — Movimento em Prol da Vida. Disponível em: <www.movitae.bio.br>. 
PESQUISAS com células-tronco dividem especialistas no STF. O Globo, 20 abr. 2007. Disponível em: <http://oglobo.globo.com/ciencia/mat/2007/04/20/ 295442915.asp>. Acesso em: 28 maio 2007.

REALE, M. Lições preliminares de direito. 24. ed. São Paulo: Saraiva, 1999. SUPREMO Tribunal Federal tenta definir o início da vida. Folha de S. Paulo, 20 abr. 2007. Disponível em: <http://www.1.folha.uol.com.br/folha/ciencia/ ult306u16321.shtml>. Acesso em 27 maio 2007.

TELLES, Maria E. R. da S. Grupos de pressão e regime representativo. São Paulo: IBEP, 1988. 